\title{
PARASITOIDS (HYMENOPTERA) OF LEAFMINER FLIES (DIPTERA: AGROMYZIDAE) FROM BANGLADESH
}

ISSN $0974-7907$ (Online) ISSN 0974-7893 (Print)

\section{OPEN ACCESS}

\author{
Santosh Mazumdar ${ }^{1}$ \& Badrul Amin Bhuiya ${ }^{2}$
}

\author{
1,2 Department of Zoology, University of Chittagong, Chittagong 4331, Bangladesh \\ ${ }^{1}$ mazumdarsantosh@gmail.com (corresponding author), ${ }^{2}$ badrulbhuiya@yahoo.com
}

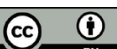

Abstract: The objective of this study was to determine hymenopteran parasitoids attacking leafminers (Agromyzidae: Diptera) in Bangladesh. Four parasitoid species, viz. Chrysocharis pentheus (Walker), Neochrysocharis formosa (Westwood) and Cirrospilus sp. belonging to family Eulophidae and Opius sp. under family Braconidae of the order Hymenoptera are reported as new to the fauna of Bangladesh. Al parasitoids were reared from three agromyzid flies namely Liriomyza sativae Blanchard, Melanagromyza obtusa Mallochand and Ophiomyia phaseoli (Tryon).

Keywords: Agromyzid leafminers, Bangladesh, new record, Parasitoids.

The leafminers (Diptera: Agomyzidae) are pests of economic importance on several vegetable and ornamental plants growing around the world. The known world of vegetable leafminers is more than 3000 species (Gençer 2004; Shahreki et al. 2012). Damage is caused by larval feeding in the spongy mesophyll layer of the leaf and by the feeding and oviposition punctures of the agromyzid females. The feeding punctures, referred to as stippling, can decrease photosynthesis and create entry sites for plant pathogens. Agromyzid larval mining can also decrease photosynthesis rates and can reduce tissue conductance (Rauf et al. 2000; Chow \& Heinz 2004). The hymenopteran parasitoid complexes associated with agromyzid flies are of great importance in biological control (Johnson 1993; Murphy \& LaSalle 1999). Parasitoids that are among natural enemy's assemblages of agromyzid leafminers are dominated by Eulophidae, Braconidae and Pteromalidae that attack the larval and pupal stages of the flies (Waterhouse \& Norries 1987; Gratton \& Welter 2001). A number of parasitoids of leafminers have been recorded throughout the world (de Roman \& de Hamity 1985; Heimpel \& Meloche 2001; Petcharat et al. 2002; Tran et al. 2005; Li \& Seal 2010). More than 140 species of parasitoids as natural enemies of Liriomyza belonging to agromyzid leafminer flies have been reported from the world (Liu et al. 2009). The present study constitutes the first record of parasitoids of agromyzid leafminers as no earlier report is available from Bangladesh.

\section{Meterials AND Methods}

A field study was carried out from January 2011 to April 2013 in different cultivated vegetable fields of Bangladesh to find out hymenopteran parasitoids of agromyzid leafminers. Leafminer-infested leaves were brought to the laboratory and kept in a controlled temperature $\left(23 \pm 1^{\circ} \mathrm{C}\right)$ and humidity $(67 \pm 2 \% \mathrm{RH})$. Leaves of different host plants were placed in plastic rearing

DOI: http://dx.doi.org/10.11609/jott.2741.8.4.8714-8718 | ZooBank: urn:Isid:zoobank.org:pub:91AF5624-4CC9-4B8E-BC40-656C181CFFD2

Editor: R.M. Sharma, (Retd.) Scientist, Zoological Survey of India, Pune, India.

Date of publication: 26 April 2016 (online \& print)

Manuscript details: Ms \# 2741 | Received 21 June 2015 | Final received 12 April 2016 | Finally accepted 14 April 2016

Citation: Santosh Mazumdar \& Badrul Amin Bhuiya (2016). Parasitoids (Hymenoptera) of leafminer flies (Diptera: Agromyzidae) from Bangladesh. Journal of Threatened Taxa 8(4): 8714-8718; http://dx.doi.org/10.11609/jott.2741.8.4.8714-8718

Copyright: (c) Mazumdar \& Bhuiya 2016. Creative Commons Attribution 4.0 International License. JoTT allows unrestricted use of this article in any medium, reproduction and distribution by providing adequate credit to the authors and the source of publication.

Funding: This study has been partially funded by USDA.

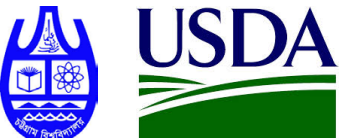

Conflict of Interest: The authors declare no competing interests.

Acknowledgements: The authors sincerely thank Dr. Mostafa Kamal Pasha, Professor, Department of Botany, University of Chittagong, Bangladesh, for identification of agromyzid plant hosts, and Dr. Md. Ismail Miah Professor, Department of Zoology, University of Chittagong, Bangladesh for his cordial help to prepare this manuscripts. 
boxes $(15 \times 25 \mathrm{~cm})$, with the rectangular holes covered with a fine screen for air ventilation. Emerging parasitoids and their host agromyzid leafminers were collected and preserved for identification. The pin and card mounted specimens were imaged with a Digital 3D imaging Microscope. For identification of agromyzid parasitoids keys provided by Gibson et al. (1997), Goulet \& Huber (1993), Narendran (2011) and Hansson (1997) were used. All identified specimens have been deposited in the Insect Museum, Department of Zoology, University of Chittagong, Bangladesh.

\section{RESULTS}

Four hymenopteran parasitoid species were reared from three agromyzid leafminers. The identified parasitoids and their leafminer hosts are given in Table 1.

\section{Chrysocharis pentheus (Walker, 1839) (Image 1)}

Entedon pentheus Walker, 1839: 38. Lectotype, designated by Graham 963b: 225, deposited in The Natural History Museum, London SW7 5BD, England. Type locality: United Kingdom. Chrysocharis pentheus (Walker).

Material studied: IMZDCU 0021, 3 males, 16.ii.2011, ex. S. lycopersicum, Hathazari, Chittagong, Bangladesh, coll. S. Mazumdar.

Diagnostic characters: Body length $1.2 \mathrm{~mm}$, metallic blue green; antenna brown, scape yellow; three-fourth of coxae and tertsae brownish; femora and tibiae pale yellow to white; forewing completely hyaline, relatively broad: 2.0-2.15 times longer than wide; pronotum small, narrow, invisible dorsally.

Host: L. sativae (Agromyzidae: Diptera) (present study), Bruchidae, Curculionidae (Coleoptera); Agromyzidae, Cecidomyiidae (Diptera); Cynipidae, Tenthredinidae (Hymenoptera); Bucculatricidae, Coleophoridae, Elachistidae, Eriocraniidae, Gelechiidae, Gracillariidae, Heliozelidae, Lyonetiidae, Momphidae, Nepticulidae, Tischeriidae, Yponomeutidae (Lepidoptera) (Noyes 2009); Agromyzidae (Diptera), Gracillariidae (Lepidoptera) (Mafi \& Ohbayashi 2010).

Distribution: Bangladesh - Chittagong (present work); Austria, Bulgaria, Canada, Canary Islands, China, Croatia, Cyprus, Czech Republic, Denmark, England, Finland, France, Germany, Greece, Hungary, Israel, Italy, Japan, Korea, Macedonia, Malaysia, Moldova, Netherlands, Norway, Poland, Romania, Slovakia, Spain, Sweden, Switzerland, Taiwan, Turkey, Ukraine, United States of America, Ussr, Serbia (Noyes 2009; Mafi \& Ohbayashi 2010).
Table 1. List of parasitoids reared from agromyzid leafminers

\begin{tabular}{|l|l|l|}
\hline & Parasitoid spp. & Host \\
\hline & Eulophidae: Entedontinae \\
\hline 1 & $\begin{array}{l}\text { Chrysocharis pentheus } \\
\text { (Walker, 1839) }\end{array}$ & Liriomyza sativae Blanchard, 1938 \\
\hline 2 & $\begin{array}{l}\text { Neochrysocharis formosa } \\
\text { (Westwood, 1833) }\end{array}$ & $\begin{array}{l}\text { Melanagromyza obtusa Malloch, 1914 } \\
\text { Liriomyza sativae Blanchard, 1938 }\end{array}$ \\
\hline & Eulophidae: Eulophinae \\
\hline 3 & Cirrospilussp. & Liriomyza sativae Blanchard, 1938 \\
\hline & Braconidae: Opiinae & $\begin{array}{l}\text { Liriomyza sativae Blanchard, 1938 } \\
\text { Melanagromyza obtusa Malloch, 1914 } \\
\text { Ophiomyia phaseoli (Tryon, 1895) }\end{array}$ \\
\hline 4 & Opius sp. \\
\hline
\end{tabular}

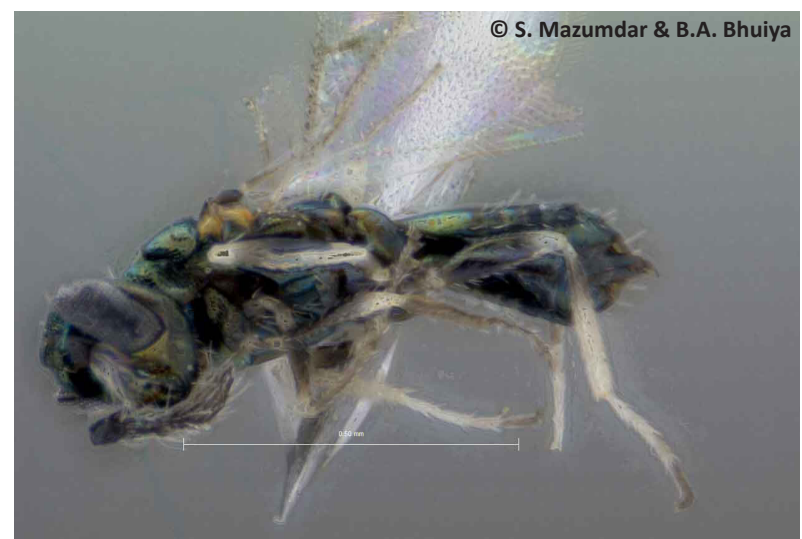

Image 1. Chrysocharis pentheus (Walker, 1839), lateral view.

\section{Neochrysocharis formosa (Westwood, 1833) (Image 2)}

Closterocerus formosus Westwood, 1833: 420. Type status unknown, deposited in Hope Department, Oxford Univeristy, Oxford, England. Type locality: United Kingdom.

Chrysocharis obscuripes; Hansson, C. 1990: 46-47. New synonym of Neochrysocharis formosa (Westwood).

Material studied: IMZDCU 008, 5 males, 23.iii.2012, ex. S. lycopersicum, Hathazari, Chittagong, Bangladesh, coll. S. Mazumdar.

Diagnostic characters: Body length: $1.6 \mathrm{~mm}$, scape almost entirely pale yellow, thoracic dorsum with strong and dense reticulation and dorsum slightly flattened; mesoscutum with notaular depressions narrow and distinct throughout; postmarginal vein 0.5-1.0 times as long as stigma vein; coxae dark metallic in contrast to legs.

Host: L. sativae (Agromyzidae: Diptera) (present study); Tuta absoluta (Gelechiidae: Lepidoptera) (Luna et al. 2011).

Distribution: Bangladesh - Chittagong, Hathazari; 


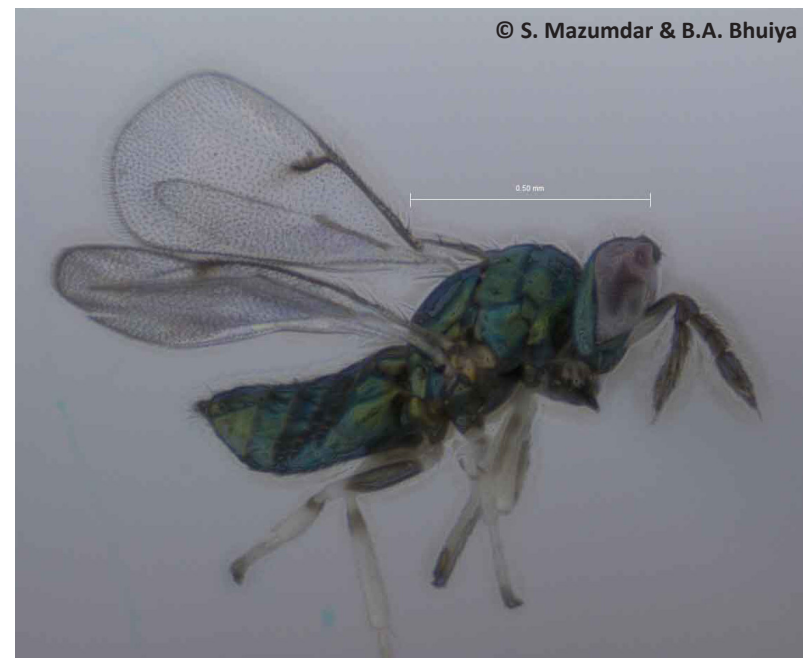

Image 2. Neochrysocharis formosa (Westwood, 1833), lateral view.

Holarctic, Mexico, North Africa and Southeast Asia (Noyes 2002, 2003), widespread distribution in West Palearctic, Nearctic region, Africa and Europe (Gençer 2004); Argentina (Luna et al. 2011).

\section{Genus Cirrospilus Westwood, 1832 (Image 3)}

Cirrospilus Westwood, 1832: 128. Type species: Gyrolasella elegantissimus Westwood; by monotypy.

Material studied: IMZDCU 009, 1 male, 06.xi.2012, ex. S. lycopersicum, Hathazari, Chittagong, Bangladesh, coll. S. Mazumdar.

Diagnostic characters: Body length $1.1 \mathrm{~mm}$; funicle 2 segmented in both sexes; notaulus usually complete, straight, ending at or near junction of anterior margin of scutellum and axilla; scutellum usually with longitudinal submedian grooves, although sometimes indistinct or even absent except for coloration; postmarginal vein at most 1.5 times longer than stigmal vein, often equal to or shorter in length; petiole very short.

Host: L. sativae (present study); Phyllocnistis citrella (Gracillariidae: Lepidoptera) (Urbaneja et al. 2001), Leafminers (Lepidoptera and Diptera) (Zhu et al. 2002).

Distribution: Bangladesh - Chittagong (present work); worldwide (Noyes 2009).

\section{Genus Opius Wesmael, 1835 (Image 4)}

Opius Wesmael, 1835: 113; Fischer, 1972b: 67-69. Type species (designation by Muesebeck and Walkley (1951), validated by ICZN Opinion 1497 (1988): Opius pallipes Wesmael, 1835.

Material studied: IMZDCU 001, 2 males, 3 females, 06.vii.2011, ex. S. lycopersicum, Hathazari, Chittagong, Bangladesh, coll. S. Mazumdar.

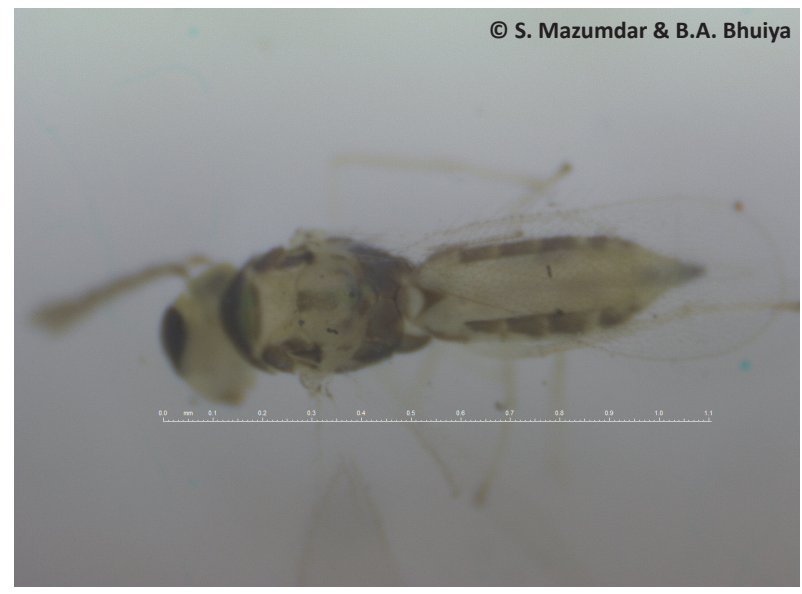

Image 3. Cirrospilus sp. dorsal view.

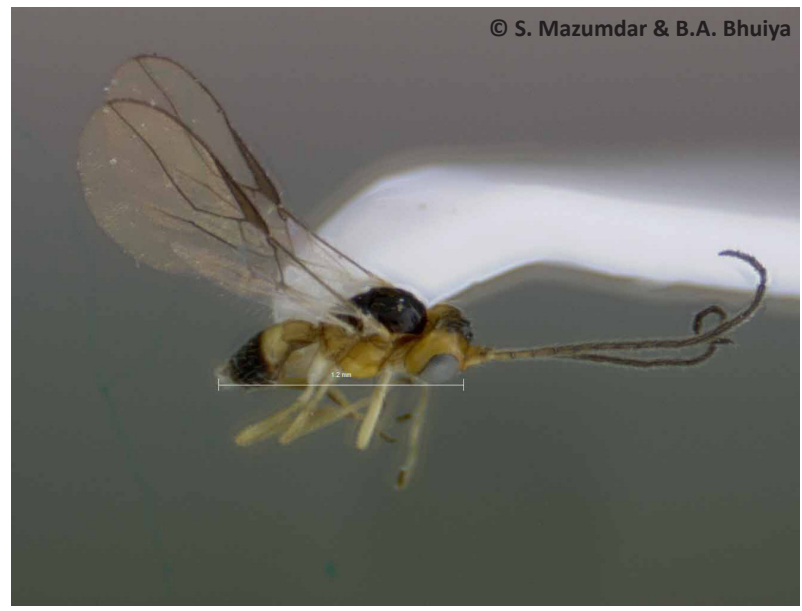

Image 4. Opius sp., lateral view

Diagnostic characters: Body length $1.2 \mathrm{~mm}$; occiput not margined; 2RS without thickening; outer margin of first subdiscal cell completely formed or first subdiscal cell apically anterior margin of clypeus rounded or straight; mandibles in the resting position closed; temple without diagonal fold in the middle; maxillary palpi 6-segmented, labial palpi 4-segmented; fore wing with three sub marginal cells; $r$ arising behind the base of the stigma; marginal cell closed; none particularly thickened vein visible; second sub marginal cell relatively elongate; mesosoma without particular colour markings, spine or process; tarsomere 2-4 not remarkably short; metasomal tergites separated through a fine suture, not uniform (fused) like structure formed or tergites not fused to form carapace.

Host: M. obtusa, $O$. phaseoli and L. sativae (present study); fruit-infesting Tephritidae, leaf-mining Agromyzidae and Anthomyiidae (Diptera) (Wharton \& 
Norrbom 2013).

Distribution: Bangladesh - Chittagong, Panchlaish, Potenga, Cox's Bazar, Rajshahi, RU campus (present work); India, Australia, Bulgaria, Brazil, Venezuela, Senegal, England, Papua New Guinea, Western And South-Eastern Australia, Philippine Islands, BismarckArchipelago, South Africa, Singapore, Argentina, Costa Rica, Colombia, Congo Republic (Belokobylskij et al. 2004; Fischer 2005; Samiuddin et al. 2009); Belgrade, Serbia and Montenegro (Brajković et al. 2005).

\section{Discussions}

The parasitoids viz. C. pentheus, N. formosa, Cirrospilus sp. and Opius sp. were recorded from three vegetable leafminers namely Liriomyza sativae; Melanagromyza obtusa and Liriomyza sativae; Liriomyza sativae; and Liriomyza sativae, Melanagromyza obtusa and Ophiomyia phaseoli respectively. In Japan, $C$. pentheus is a very common parasitoid of Agromyzidae such as: Agromyza albipennis Meigen, A. oryzae Munakata, Phytomyza horticola Gourea, P. ranunculi Schrank, P. paniculatae Sasakawa, Calycomyza humeralis Roser, and Agromyzid sp. on Gentiana (Mafi \& Ohbayashi 2010) where as C. pentheus has been found in L. sativae (Agromyzidae: Diptera) in the present study. Moreover, Luna et al. (2011) reported $N$. formosa as a parasite of Tuta absoluta (Gelechiidae: Lepidoptera) where as it has been reared from L. sativae (Agromyzidae: Diptera) in the present study. In addition, among them $N$. formosa was the most abundant species accounting for approximately $57 \%$ of all reared parasitoids. A total number of 22 species of genus Cirrospilus has been described in North America, (Burks 1979; Gates 2000). In addition, Zhu et al. (2002) provided a key to twenty Chinese Cirrospilus species. C. vittatus was reared from leafminers $L$. sativae and $L$. trifolii in Iran (Asadi et al. 2006). Besides, Urbaneja et al. (2001) reported it as a pest of Phyllocnistis citrella (Gracillariidae: Lepidoptera). In the present study only a single specimen of Cirrospilus sp. was found from L. sativae. As a parasitoid of Ophiomyia phaseoli, Opius phaseoli was recorded in East Africa and Ethiopia (Greathead 1975; Abate 1991; Waterhouse 1998). The rapid control of Ophiomyia phaseoli was achieved in Hawaii following the introduction of Opius phaseoli and O. importatus (Waterhouse 1998). Chen \& Weng (2005) published an overview of the Opiinae from China where he listed 121 species. Nineteen new Indian species of the genus Opius under the subfamily Opiinae were described by Samiuddin et al.(2009). On the other hand, Opius sp. has been reported in the present study for the first time. This species has been collected from
M. obtusa; O. phaseoli and L. sativae. The present investigation reveals that Opius sp. is a comparatively common parasitoid among other reared parasitoids obtained from the three agromyzid flies.

\section{CONCLUSION}

This study implies that these native parasitoids might be considered for control of agromyzid leafminer pests.

\section{REFERENCES}

Abate, T. (1991). The bean fly, Ophiomyia phaseoli (Tryon) (Dipt., Agromyzidae), and its parasitoids in Ethiopia. Journal of Applied Entomology 111(1-5): 278-285; http://dx.doi. org/10.1111/j.1439-0418.1991.tb00324.x/abstract

Asadi, R., A.A. Talebi, Y. Fathipour, S. Moharramipour \& E. Rakhshani (2006). Identification of Parasitoids and Seasonal Parasitism of the Agromyzidae Leafminers Genus Liriomyza (Diptera: Agromyzidae) in Varamin, Iran. Journal of Agricultural Science and Technology 8: 293-303.

Belokobylskij, S.A., R.A. Wharton \& J.L. Salle (2004). Australian species of the Genus Opius Wesmael (Hymenoptera: Braconidae) attacking leaf-mining Agromyzidae, with the description of a new species from South-east Asia. Australian Journal of Entomology 43: 138-147.

Bhat, D.M. \& R.C. Bhagat (2011). Natural Parasitism of Leaf Miner, Chromatomyia horticola (Goureau) (Diptera: Agromyzidae) on Vegetable Crops in Kashmir (India). Academic Journal of Plant Science 4(2): 30-33.

Brajković, M.M., Z. Nikolić \& S.B. Ćurčić (2005). On the entomofauna of Mt. Durmitor (Northern Montenegro): braconid wasps of the subfamily Opiinae (Braconidae, Hymenoptera). Archives of Biological Sciences 57(2): 151-155.

Burks, B.D. (1979). Family Eulophidae, pp. 967-1022. In: Krombein, K.V., P.D. Hurd, Jr., D.R. Smith \& B.D. Burks, (eds.). Catalog of Hymenoptera in America North of Mexico. Smithsonian Institution Press, Washington DC.

Chen, J.H. \& R.Q. Weng (2005). Systematic studies on Opiinae of China (Hymenoptera: Braconidae). Fujian Science and Technology Publishing House, Fujian, volume I-III, 1-2, 1-9, 1-269.

Chow, A. \& K.M. Heinz (2004). Biological control of leafminers on ornamental crops, pp. 221-238. In: Heinz, K.M., R.G. van Driesche \& M.P. Parrella (eds.). Biocontrol in Protected Culture. Ball Publishing, Batavia, Illinois.

de Roman, L.E.N. \& M. G.A. de Hamity (1985). Parasitoids of Liriomyza huidobrensis in the Quebrada De Humahuaca (Jujuy). Neotropica 31: 181-186.

Fischer, M. (2005). Some new Opiinae (Insecta: Hymenoptera: Braconidae) in the Natural History Museum Vienna. Annalen des Naturhistorischen Museums in Wien 106B: 107-133.

Gates, M. (2000). A new species of Cirrospilus Westwood (Hymenoptera: Eulophidae) from the southwestern United States and Mexico. Proceedings of the Entomological Society of Washington 102: 58-61.

Gençer, L. (2004). A Study on the Chalcidoid (Hymenoptera: Chalcidoidea) Parasitoids of Leafminers (Diptera: Agromyzidae) in Ankara Province. Turkish Journal of Zoology 28: 119-122.

Gibson, G.A.P., J.T. Huber \& J.B. Woolley (eds.) (1997). Annotated Keys to The Genera of Nearctic Chalcidoidea (Hymenoptera). National Research Council of Canada, Ottawa, xi+794pp.

Goulet, H. \& J.T. Huber (eds.) (1993). Hymenoptera of The World, An Identification Guide to Families. Agriculture Canada Publications, Ottawa, Canada, 668p.

Gratton, C. \& S.C. Welter (2001). Parasitism of natural populations of Liriomyza helianthi Spencer and Calycomyza platyptera (Thomson) 
(Diptera: Agromyzidae). Biological Control 22: 81-97.

Greathead, D.J. (1975). Biological Control of the bean fly Ophiomyia phaseoli (Diptera: Agromyzidae) by Opius spp. (Hymenoptera: Braconidae) in the Hawaiian Islands. Entomophaga 20(3): 313-316.

Hansson, Ch. (1997). Survey of Chrysocharis Forster and Neochrysocharis Kurdjumov (Hymenoptera, Eulophidae) from Mexico, including eight new species. Miscellania Zoologica 20 (1): 81-95.

Heimpel, G.E. \& F. Meloche (2001). Biological control of alfalfa blotch leafminer (Diptera: Agromyzidae) in Ontario: status and ecology of parasitoid (Hymenoptera: Braconidae, Eulophidae) 20 years after introduction. Great Lakes Entomologist 34 (1): 17-26.

Johnson, M.W. (1993). Biological control of Liriomyza leafminers in the Pacific Basin. Micronesica Supplement 4: 81-92.

Li, J. \& D.R. Seal (2010). Parasitoids of Dipteran leafminers, Diglyphus spp. (Insecta: Hymenoptera: Eulophidae); EENY-484 (IN877), Entomology and Nematology Department, Florida Cooperative Extension Service, Institute of Food and Agricultural Sciences, University of Florida.

Liu, T.X., L. Kang, K.M. Heinz \& J.T. Trumble (2009). Biological control of Liriomyza leafminers: progress and perspective. CAB Reviews: Perspectives in Agriculture, Veterinary Science, Nutrition and Natural Resources 4(004): 1-16.

Luna, M.G., V.I. Wada, J.L. Salle \& N.E. Sánchez (2011). Neochrysocharis formosa (Westwood) (Hymenoptera: Eulophidae), a newly recorded parasitoid of the Tomato Moth, Tuta absoluta (Meyrick) (Lepidoptera: Gelechiidae), in Argentina. Neotropical Entomology 40(3): 412-414.

Mafi, S. \& N. Ohbayashi (2010). Biology of Chrysocharis pentheus, an Endoparasitoid Wasp of the Citrus Leafminer Phyllocnistis citrella Stainton. Journal of Agricultural Science and Technology 12: 145154.

Murphy, S.T. \& J. La Salle (1999). Balancing biological control strategies in the IPM of New World invasive Liriomyza leafminers in field vegetable crops. Biocontrol News Inform 20: 91N-104N.

Narendran, T.C. (2011). Fauna of India and the Adjacent Countries: Eulophinae: Hymenoptera: Eulophidae. Zoological Survey of India, Kolkata, 342pp.

Noyes, J.S. (2002). Interactive Catalogue of World Chalcidoidea (2001 second edition). CD-Rom. Taxapad and the Natural History Museum, London, UK.

Noyes, J.S. (2003). Universal Chalcidoidea Database. World Wide Web electronic publication; www.nhm.ac.uk/entomology/chalcidoids/ index.
Noyes, J.S. (2009). Universal Chalcidoidea Database. World Wide Web electronic publication; www.nhm.ac.uk/entomology/chalcidoids/ index

Petcharat, J., L. Zeng, W. Xu, Z. Zhang \& Q. Wu (2002). Larval parasitoids of agromyzid leaf miner genus Liriomyza in the southern Thailand: Species and their host plants Songklanakarin. Journal of Science and Technology 24(3): 467-472.

Rauf, A., B.M. Shepard \& M.W. Johnson (2000). Leafminers in vegetables, ornamental plants and weeds in Indonesia: surveys of host crops, species composition and parasitoids. International Journal of Pest Management 46: 257-266.

Samiuddin, A., Z. Ahmad \& M. Shamim (2009). Taxonomic studies of the genus Opius (Hymenoptera: Braconidae: Opiinae) from India. Oriental Insects 43: 159-199.

Shahreki, Z., E. Rakhshani \& M. Sasakawa (2012). A Contribution to the agromyzid leaf miners (Diptera: Agromyzidae) of Iran. Biologicanyssana 3 (1): 31-36.

Tran, D.H., M. Takagi \& K. Takasu (2005). Toxicity of Selective Insecticides to Neochrysocharisformosa (Westwood) (Hymenoptera: Eulophidae), a parasitoid of the American serpentine leafminer Liriomyza trifolii (Burgess) (Diptera: Agromizydae). Journal of Faculty of Agriculture. Kyushu University 50: 109-118.

Urbaneja, A., E. Llácer, A. Garrido \& J.A. Jacas (2001). Effect of variable photoperiod on development and survival of Cirrospilus sp. nr. Lyncus (Hymenoptera: Eulophidae), an ectoparasitoid of Phyllocnistis citrella (Lepidoptera: Gracillariidae). Florida Entomologist 84(2): 305-307.

Wharton, R. \& A.L. Norrbom (2013). New species and host records of New World, mostly Neotropical, opine Braconidae (Hymenoptera) reared from flower-infesting, stem-galling, and stem-mining Tephritidae (Diptera). ZooKeys 349: 11-72.

Waterhouse, D.F. (1998). Biological Control of Insect Pests: Southeast Asian Prospects. Australian Centre for International Agricultural Research (ACIAR) Monograph No. 51, viii+548pp.

Waterhouse, D.F. \& K.R. Norries (1987). Liriomyza species (Diptera: Agromyzidae) leafminers, pp. 159-176. In: Waterhouse, D.F. \& K.R. Norris (eds.), Biological control: Pacific prospect. Inkata Press, Melbourne, Australia.

Zhu, C.D., J. LaSalle \& D.W. Huang (2002). A Study of Chinese Cirrospilus Westwood (Hymenoptera: Eulophidae). Zoological Studies 41(1): 23-46.

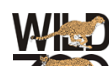

